\title{
Electron microscopic observations of the anterior pituitary of the mouse
}

\author{
By \\ Kazumaro Yamada and Masao Sano \\ Department of Anatomy, Nagoya University School of \\ Medicine, Nagoya, Japan \\ (Director: Prof. Dr. K. Y a mada)
}

\section{Introduction}

Since the studies of Fle sch (1884) and S ch ön e mann (1892), a number of informations on the anterior pituitary cytology have been published. Based upon these reports, parenchymatous cells of the anterior pituitary have been divided into three cell types (acidophile, basophile and chromophobe cells). On the other hand, a modern classification of pituitary secretory cells was established by the contributions of Romeis ('40), Catch pole ('49), Pearse ('49, '50, '52a, '52b, '53), Hal mi ('50, '52) and P u r ve s and Gr i e sb a c h ('51a, '51b, '51c, '54, '55). In our laboratory, parenchymatous cells of the mouse anterior pituitary were classified into acidophiles, basophiles (beta- and delta-cells), theta-cells and chromophobes by light microscopy ( Y a mada, S a no and Ito, '57; S a n o, '58).

Recently the application of electron microscopy to cytology and histology has greatly developed. This depends on improvements in methods of fixation ( Pal ade, '52a), embedding ( $N$ e w ma n, B o r ysko and Swerdlow, '49; Borysko, '56a, '56b) and sectioning (Latta and Hartmann, '50; Porter and Blum, '53; Ferná nd e z-Morán, '56). Thus, a number of organs, tissues or cells have been made to reveal their finer structures.

The anterior pituitary was first studied by Fe rá nde z-Mor á n and L u f t ('49) by electron microscopy applying the replica technique. Subsequently, several studies were made on sections (We is s and La n s ing, '53; R ine hart and Farquhar, ' 53 , '55; Farquhar and Rinehart, '54a, '54b; Green and Van Breemen, '55; Farquhar and Wellings, '57; Peterson, '57; Farquhar, 
'57; I c h i k a wa, '59). According to these authors, parenchymatous cells of the anterior pituitary are composed of three kinds of cells and they were compared with the hitherto well-known cell types of light microscopy; acidophile, basophile and chromophobe cells. Farquhar and $\mathrm{R}$ inehart ('54a, '54b) in the rat pituitary differentiated thyrotrophs and gonadotrophs which are subtypes of basophiles. They also distinguished two types of gonadotrophs which may be LH- and FSH-producers. Quite recently Far quhar ('57) postulated the presence of "corticotrophs" in the rat anterior pituitary by electron microscopy. Further, $R$ inehart and Farquhar ('55) reported on a fine vascular organization in the rat anterior pituitary and discussed its functional implications in hormone supply.

The present authors preliminarily reported on the anterior pituitary cytology of the mouse ( $\mathrm{Y}$ a ma d a and $\mathrm{S}$ a $\mathrm{n}$ o, '58). In the present paper, it is shown that besides the three principal cell types mentioned above, there are found some additional cell types in the mouse anterior pituitary, while some data on the structure of capillary walls different from those reported by $\mathrm{R}$ ine hart and $\mathrm{Far}$ q u har ('55) were obtained.

\section{Material and Methods}

Adult mice of both sexes ranging from 60 to 150 days of age were used. Mice were killed under chloroform anesthesia. Pituitaries obtained were fixed with $1 \%$ osmium tetroxyd solution buffered ( $\mathrm{pH} 7.2$ to 7.5 ) according to the method of $\mathrm{Palade}$ ('52a). The fixation was carried out in a refrigerator at 3 to $5^{\circ} \mathrm{C}$ for about one hour. Then the materials were washed in destilled water and dehydrated in graded series of ethyl alcohol. They were embedded in a mixture of 9 parts of n-buthyl methacrylate and one part of methyl methacrylate. Polymerization was accomplished in an oven at $45^{\circ} \mathrm{C}$ for about 24 hours. Materials were cut with a thermal expansion microtome (JUM-3 type) prepared by Japan Electron Optics Laboratory Co., Ltd. and glass knives were used. Without removal of embedding material, specimens were examined with a JEM-T1 type electron microscope manufactured by Japan Electron Optics Laboratory Co., Ltd. Selected fields were photographed with initial magnifications of 2500 to 5000 times and enlarged photographically. 


\section{Observations}

As regards the anterior pituitary cytology of the mouse, the present authors previously published some observations by light microscopy (Y a mad a, S a no and I to, '57; S a n o, '58) and divided the parenchymatous cells into four differentiated cell types (alpha-, beta-, delta- and theta-cells) and one undifferentiated cell type (chromophobe cell). The present authors found five cell types in the mouse anterior pituitary by electron microscopy. In this paper the parenchymatous cells will be provisionally classified into the first, second, third, fourth and fifth types according to the morphology of their cytoplasmic granules.

\section{The first type cell}

This type cell (Figs. 1, 2, 3, 4, 5, 6, 7) contains the largest granules in the cytoplasm among the anterior pituitary cells. Based upon the observations of numerous electron micrographs, it is clear that this is the most frequently observed cell type in the anterior lobe. From the size of the cytoplamic granules, it is conceivable that these cells are comparable to acidophiles in light microscopy. In the majority of electron micrographs, these cells are rounded or oval in shape and have a well-defined cell membrane. Nuclei of these cells are in general eccentrically located. They show a fine granular appearance and have some nucleoli more electron dense than other nuclear area.

In the cytoplasm of this type cell are observed cytoplasmic granules, endoplasmic reticulum, mitochondria and Golgi complex. Electron dense, clearly delineated, rounded granules are contained in variable numbers in each cell. The maximum diameter of these granules is approximately $350 \mathrm{~m} \mu$ in general and occasionally reaches to $400 \mathrm{~m} \mu$. Since in individual cells these granules are variable in diameter and indicate always a rounded contour in all microgaphs examined, they will be spherical in tridimensional structure. Cytoplasmic granules arrange in a row at the cell periphery in some cells, they are randomly scattered in the cytoplasm in some others, and in still others these granules are densely packed in a cluster at a pole of the cytoplasm against the nucleus. But, as a rule, the perinuclear areas are devoid of these granules. With the present resolving power, these granules appear homogeneous. 
At the perinuclear area, an ill-defined dark region is observed and this dark region contains many vacuolar spaces, small vesicles and lamellar structures. In the light of many literatures as will be shown afterwards, this area will represent the Golgi complex. These dark areas observed in many cells of this type are oval, elongated, or cord-like in shape. Moderately granulated cells are provided with a well-developed Golgi complex (Fig. 6). In cells with a dense mass of cytoplasmic granules the Golgi area is not so extensive as in the moderately granulated cells. Sparsely granulated cells and sometimes cells with dense granulation have no Golgi complex. In the Golgi area of this type cell cytoplasmic granules are sometimes observed.

Mitochondria are scattered randomly in the cytoplasm. In sections they are generally rod-like or oval in shape and are provided with clear cristae mitochondriales.

The endoplasmic reticulum is generally well-developed in this cell type. It is located predominantly at the perinuclear region. Dilated cavities of the endoplasmic reticulum are frequently observed, especially in the cells with moderate granulation. Thus, cytoplasmic ground substances occasionally remain like islands or cords between these dilated cavities (Fig. 2). Occasionally the limiting membranes of the endoplasmic reticulum connect with the outer nuclear membrane (Figs. 1, 2) and with the cell membrane.

Rarely a condensed form of this type cell is observed (Fig. 5). Such a cell is characterized by an electron dense, homogeneous, bizarre-shaped, compact nucleus, an extensive irregular-shaped perinuclear gap which seems to be the dilated cavities of the endoplasmic reticulum, compressed appearance of granule accumulation and the electron dense cytoplasm.

\section{The second type cell}

These cells (Figs. 1, 3, 4) have smaller cytoplasmic granules than those of the first type cell. These cells are comparable to basophile cells in light microscopy from the size of the cytoplasmic granules. The second type cells are frequently observed though less in number than the first type cell. These cells are variable in shape; some indicate rounded or oval contour, some a polygonal, compressed figure and still others pseudopodien-like processes. Nuclei of these cells indicate a similar appearance as those of the first type cells. 
Cytoplasmic granules are well-defined. The maximal diameter of them generally measures about $150 \mathrm{~m} \mu$ and rarely attains to $200 \mathrm{~m} \mu$. They are electron dense and indicate a circular profile. These granules are contained in variable numbers from one cell to another and are generally arranged in a row at the cell periphery, but frequently cells are observed with randomly scattered granules in the cytoplasm except the perinuclear region. The Golgi complex is rounded or oval in shape and is more clearly recognizable than in the first type. Frequently cytoplasmic granules are observed in the Golgi area in small numbers. As in the first type cell, mitochondria of this type cell indicate rod-like or oval profile in sections. They have cristae mitochondriales and are located randomly in the cytoplasm. The endoplasmic reticulum is not so well-developed as in the first type. Limiting membranes of the endoplasmic reticulum are closely apposed to each other in general (Figs. 3, 4) and dilated cavities of this system are less frequently observed than in the first type (Fig. 1).

\section{The third type cell}

This type cell (Fig. 3) contains no cytoplasmic granule. In a strict sense, identification of this cell type must depend on observations of serial electron micrographs revealing an entire cell body. But it is difficult to obtain such serial sections at present. For convenience here, cells without cytoplasmic granules in individual electron micrographs were involved in this cell type. It is clearly that these cells correspond to chromophobe cells, but cells of this type were found to be surprisingly rare in electron microscopy when compared with light microscopy. These cells are relatively small in size and variable in shape. Nuclei of these cells indicate a similar appearance as those of the first and second type cells. In the cytoplasm, ill-defined small particles (granular or vesicular) are diffusely scattered. Mitochondria are rod-like or oval in general and are randomly scattered in the cytoplasm. These cells contain no or poorly-developed endoplasmic reticulum and almost always have no Golgi complex.

\section{The fourth type cell}

This type cell (Figs. 1, 4, 9) is provided with electron dense granules. These granules are kidney-shaped, rod-like, polygonal, 
elliptical, triangular or irregular-shaped and considerably vary in size. They are scattered individually or in small masses at the cell periphery. Frequently cytoplasmic granules are observed in the Golgi area in clusters (Fig. 4), being smaller in size than those at the cell periphery. This type cell generally contains fewer cytoplasmic granules than the first and second type cells. The Golgi area of the fourth type cell is extensive, well-defined and rounded or oval in shape. Mitochondria are scattered in the cytoplasm as in the first, second and third type cells. Well-developed endoplasmic reticula are observed (Figs. 1, 4). They are arranged characteristically; they appear to be disposed parallel to one another at more or less regular intervals. The entire arrangement of these is concentric with the nucleus, and parallel to the cell membrane. These endoplasmic reticula are located considerably extensively in the cytoplasm from nucleus to cell periphery. Sometimes, membrane bound cavities of the endoplasmic reticulum are expanded into broad sinuses though not so marked as in the first type cell. There was sometimes observed a connection between the cell membrane and limiting membrane of the endoplasmic reticulum (Fig. 9). The fourth type cells vary in incidence in different animals, and are frequently seen in some and rarely in others. The nucleus of this type cell does not show an appearance different from those of the first, second and third type cells.

\section{The fifth type cell}

These cells (Fig. 6) contain no characteristic cytoplasmic granules such as in the first, second, and fourth type cells. But ill-defined small particles are diffusely scattered in considerable numbers in the cytoplasm. These particles are rounded in shape and less dense than the cytoplasmic granules of the first, second or fourth type cell, although they vary in density. They are somewhat larger than the granules of the second type cell, but smaller than those of the first type cell. Each particle is generally enveloped by a halo variable in width. The Golgi complex is well-developed in general. Numerous mitochondria are contained in this type cell. The endoplasmic reticulum is found to be poorly-developed in general. The nucleus of this type cell is similar in appearance to the other type cells mentioned above. 


\section{Vascular organization}

The capillary lumen is lined by a layer of endothelial cells. Nuclei of endothelial cells are variable in shape and are more electron dense when compared with those of parenchymatous cells. The cytoplasm of the endothelial cells is abundant in the vicinity of the nucleus and scarce at the distal regions, where the cytoplasm is attenuated and occasionally fenestrated (Figs. 7, 8). In sections perpendicular to the capillary wall, discontinuity of the endothelial cell cytoplasm can be observed. But the fenestrated cytoplasm is frequently bridged by a thin membrane. In tangentially sectioned portions, on the other hand, there are found numerous pores (Figs. 9,10 ). In the area adjacent to the nucleus the endoplasmic reticulum, mitochondria and Golgi complex are frequently observed (Fig. 7). Subjacent to the endothelial cell cytoplasm a membrane is observed (Fig. 8). Also a similar membrane is closely apposed to the free surface of parenchymatous cells facing the sinusoids. These two membranes are less dense and thicker than the cell membrane and appear homogeneous with the present resolution. By these two nembranes which were called inner and outer basement membranes by $\mathrm{Rinehart}$ and Farquhar ('55) the perisinusoidal space is bordered (Figs. 7, 8). The space is variable in width. Thus, the parenchymatous cells are separated from capillary spaces by the endothelium, inner basement membrane, perisinusoidal space and outer basement membrane. In the perisinusoidal space, the present authors could not find fragments of parenchymatous cells seen in the case of $\mathrm{Rinehart}$ and Farquhar ('55).

\section{Discussion}

We is s and Lan s in g ('53) in the anterior pituitaries of Swiss albino mice observed three cell classes and stated that formed elements of these cells are represented by cytoplasmic granules (100 to $500 \mathrm{~m} \mu$ in diameter), double menbraned system and mitochondria. According to their results, although chromophobes do not have granules, acidophiles contain abundant granules, while in basophiles they observed a scarcity in number of cytoplasmic granules. In addition, the granules, which are present in all three groups, did not differ in appearance. In the present observations, however, cytoplasmic granules contained in cells of different types were clearly 
different in size and arrangement. Similar results were reported by $\mathrm{R}$ in ehart and Farquhar ('53).

$\mathrm{R}$ in e hart and F a q u har (53) in the rat anterior pituitary found three cell types (acidophiles, basophiles and chromophobes). Chromophobes were without or contained only few granules, acidophiles had large granules $350 \mathrm{~m} \mu$ in maximal diameter and basophiles contained small granules (140 to $200 \mathrm{~m} \mu$ in diameter). Furthermore, based upon their cytoplasmic granules and other cytological details, they differentiated five cell types; besides two types of acidophiles, three varieties of basophiles (thyrotrophs and gonadotrophs which were further divided into LH-producing and FSH-producing cells) (F a rquhar and Rinehart, '54a, '54b). Peterson ('57) also divided basophiles into three types by electron microscopy and the PAS technique. Recently F a r q u har ('57) designated the "corticotrophs" in the rat by electron microscopy.

In the present paper, the cell types of the mouse anterior pituitary were provisionally named by ordinal numbers. From the size of cytoplasmic granules and other features, it is clear that the first, second and third cell types correspond respectively to acidophile, basophile and chromophobe cells of light microscopy. In the fourth type cells, kidney-shaped, angular or irregular-shaped granules and concentrical arrangement of the endoplasmic reticulum were characteristic. But it is obscure at present what class cell of light microscopy corresponds to the fourth type cell. The fifth type cells contained many small particles randomly scattered throughout the cytoplasm. These small particles were ill-defined, rounded and though variable in density, were less dense than cytoplasmic granules of other type cells. These particles were smaller than granules of the first type cell and larger than those of the second, although they could not be strictly measured on account of their ill-defined profiles. The fifth type cell may represent a transitional form(s) from the third type to other cell types. Because it is assumed that from their size and density these small particles may be a precursor of cytoplasmic granules of cells of the other type(s). In this paper, cells which contain no cytoplasmic granule in individual electron micrographs were classified as the third type cells (chromophobe). Strictly speaking the third type cells may involve other type cells with only few cytoplasmic granules, because the present authors did not examine serial sections representing an entire cell body. Chromophobes were most frequently found in light microscopy, while in 
electron microscopy the third type cells are rarely observed. This is because that in light microscopy cells which should be classified as chromophiles are counted as chromophobes because of the scarcity of their cytoplasmic granules. Thus, as previously reported ( $\mathrm{Y}$ a $\mathrm{m}$ ad a, S a no and Ito, '57; Sa no, '58), chromophobes of light microscopy will involve degranulated forms of chromophiles, besides true chromophobes in a strict sense of the word. On the other hand, in electron microscopy, the third type cells generally contained no Golgi complex and no or poorly-developed endoplasmic reticulum. It is highly probable that the third type cells represent cells in a resting phase as shown by $\mathrm{R}$ in e hart and Far qu har ('53). A condensed form of the first type cell could be easily recognized by its characteristic feature. At present it is not clear whether these cells represent a physiological functional stage of this cell type or artefacts resulting from preparation procedures.

In the cytoplasm of parenchymatous cells, there were observed as well-formed elements, Golgi's apparatus, endoplasmic reticulum and mitochondria besides cytoplasmic granules mentioned above.

The ultrastructure of Golgi's apparatus has been described by a number of authors. At present, although a different opinion has been advocated by a group of investigators ( $\mathrm{P}$ a l a d e and $\mathrm{Cla} \mathrm{ude}$, '49a, '49b; Palade, '55b; P a la y and P a lade, '55), it is predominantly believed that what contains vacuoles, small vesicles or granules and lamellar structures within electron dense ground substance is what is called Golgi complex and this complicated structure corresponds to the Golgi apparatus of light microscopy (Dalto $\mathrm{n}$, '52; Sjöstrand and Hanzon, '54b; Dalton and Felix, '54, '56; Afzelius, '56; Beams, Tahmisian, Devine and Anderson, '56; Lacy, '57 and others). In such a sense, the present authors found the Golgi complex in all cell types except the third type cells. The Golgi complex of the first type cell was variable in size from cell to cell. Densely granulated cells generally contained no or small Golgi complex, but moderately granulated cells were provided with large one. Farquhar and W ell i $\mathrm{ngs}$ ('57) pointed out the presence of cytoplasmic granules within the Golgi vesicles in the rat anterior pituitary acidophiles. They assumed that granule formation may occur within the Golgi apparatus in these cells. Also in the present results cytoplasmic granules located within smooth surfaced vesicles were found. But this occurred so rarely that it 
is unable from the present data to determine whether or not cytoplasmic granules are produced within the Golgi vesicles. In the first type cell, cytoplasmic granules were found in clusters or in a row at the cell periphery and were sometimes encountered in the Golgi area, while in the second type cell, cytoplasmic granules were frequently contained in the Golgi area, though not so large as mature granules in size. The Golgi area of this type cell was extensive and well-defined when compared with that of the first type cell. The Golgi area of the fourth type cell was also extensive and welldefined in general. In the Golgi area of this type cell considerably numerous cytoplasmic granules were frequently found though smaller in size than those at the cell periphery. The precise relationship between these granules and components of the Golgi complex is obscure at the present level of resolution.

As regards the functional significance of the Golgi apparatus, many informations are available (see review of $\mathrm{Kirkman}$ and Severinghaus, '38). By application of electron microscopy, $\mathrm{Sjöstrand}$ and $\mathrm{Hanz}$ on ('54b) in the mouse pancreas found an intimate relationship between the zymogen granules and the Golgi granules or vesicles. H a g u e $\mathrm{n} \mathrm{a} \mathrm{u}$ and $\mathrm{B}$ e r $\mathrm{n} \mathrm{h}$ a r d ('56) in a survey of the Golgi complex, drew similar conclusions on the formation of secretory granules in the anterior pituitary. In the mouse pancreatic acinar cells as well as in the rat anterior pituitary acidophiles F a r q h a r and W elli $\mathrm{ngs}$ ('57) obtained similar results. Hally ('58) assumed that the secretory granule of the Paneth cell arises from a vacuole within the Golgi complex and becomes a small secretory granule. From the present results, the present authors prefer the opinion that the Golgi apparatus is associated with the production of secretory granules.

In 1880 Heidenhain (see $\mathrm{Z}$ i mmerma n n, '27) observed the existence of lamellar structures in the exocrine pancreas cells and called them "Basallamellen" or "Ergastoplasma." At the present time, it is certain that the endoplasmic reticulum found by electron microscopy corresponds to the "Basallamellen" or "Ergastoplasma" observed with the light microscope. This structure called endoplasmic reticulum by $\mathrm{P}$ orte $\mathrm{r}$ and $\mathrm{Ka} / \mathrm{lm}$ a $\mathrm{n}$ ('52) has been described under a variety of names by many workers. It is well known at present that this structure represents the basophilic components of the cytoplasm and that it is composed of the network of membrane 
bound cavities (endoplasmic sacs) and small particles attached to its outer surface (B e r nhard, $\mathrm{Hag}$ u ena $\mathrm{u}, \mathrm{Gautier}$ and $\mathrm{Ober-}$ li ng, '52; W e is s, '53; P orter, '53, '54; Pal ad e and Porter, '54; S jöstrand and Hanzon, '54a; Palade, '55a, '55b, '56a; $\mathrm{Clermont}$, '56; Porter and Palade, '57; Finck, '58; Sieke$\mathrm{vitz}$ and $\mathrm{Palade}$ ' 58 and others). This system was encountered in all kinds of animal cell except erythrocytes ( $\mathrm{P}$ a l a d e, '55b).

The first tyre cells were generally provided with well-developed endoplasmic reticulum especially in the perinuclear region. Membrane bound cavities of the endoplasmic reticulum frequently showed sinuslike dilatation and occasionally ground substances of the cytoplasm were scattered like islands between these cavities. Wat a nabe ('57) illustrated tridimensional figures of intracytoplasmic sacs (endoplasmic reticulum). According to him, the intracytoplasmic sacs vary considerably in shape due to fenestration, anastomosis and dilatation of them. In the first type cells, profiles of the endoplasmic reticulum showed variations of considerable extent from cell to cell. Sinus-like dilatation of cavities of the endoplasmic reticulum was conspicuous in moderately granulated cells when compared with cells showing dense granulation and cells with scarce granules. On the other hand, the fourth type cell also contained well-developed endoplasmic reticulum. The endoplasmic reticulum of this type cell showed a concentrically parallel arrangement in the cytoplasm from the perinuclear region to the cell periphery. Sinus-like dilatation of cavities of the endoplasmic reticulum was not so marked as in the first type cell. Similar features of the endoplasmic reticulum were reported in exocrine cells of the pancreas (Sjöstrand and $\mathrm{Hanzon}$, '54b), in the Peneth cell (H a lly, '58) and in plasma cells (Watanabe, Takamats u and Osako, '55). The endoplasmic reticulum of the second type cells was generally not so well-developed as in the first and fourth type cells, and was irregularly arranged in the cytoplasm. Membrane bound cavities of the endoplasmic reticulum showed generally a narrow space and the sinus-like dilatation was observed occasionally. The majority of the third type cells contained no endoplasmic reticulum.

$\mathrm{P}$ a l a d e ('55b) and W a t s on ('55) observed a connection between the outer nuclear membrane and the limiting membrane of the endoplasmic reticulum. They postulated that the perinuclear space is continuous with cavities of the endoplasmic reticulum. Moreover, continuity of the cell membrane with the limiting membrane of the 
endoplasmic reticulum was also found in macrophages ( $\mathrm{P}$ a l a d e, '55b) and in the epididymis ( $\mathrm{L}$ a d m a $\mathrm{n}$ and $\mathrm{Y}$ o u $\mathrm{ng}$, '58). Thus, it may be accepted that the perinuclear spase communicates with the extracellular region through the network of cavities of the endoplasmic reticulum. In the light of these data, $\mathrm{P}$ a la $\mathrm{d}$ e asserted that we may have in the endoplasmic reticulum a system involved in the import, export, and intracellular circulation of various substances. In the present data, the continuity between outer nuclear membrane and endoplasmic reticulum was frequently found especially in the first type cells. There was also occasionally observed the connection between the cell membrane and limiting membrane of the endoplasmic reticulum in the first and fourth type cells. But it is not clear with the present resolving power whether this connection is due to true fusion of both membranes or depends on close contact or apposition of them. Although the functional significance of the endoplasmic reticulum is a problem which should be resolved by further studies, based on its feature in the first and fourth type cells the endoplasmic reticulum may be related with solution and release of cytoplasmic granules, in agreement with the opinion of $\mathrm{Rine}$ hart and Farqu har ('53).

Studies on the fine structure of mitochondria with the electron microscope have been made by a number of authors (P a la d e, '52b, '53; S jöstrand, '53; S jöstrand and R hodin, '53; S jöstrand and $\mathrm{H}$ a n z on, '54a; $\mathrm{R}$ hod i n, '54; Fre e ma n, '56 and others). It is clear that mitochondria represent multienzyme system and are associated with cell respiration (see $\mathrm{P}$ a l a d e, '56b). In the present study, mitochondria were found in all cell types. They were rounded, oval, elongated or rod-shaped in sections and showed clearly cristae mitochondriales in general. Mitochondria were found to be few in third type cells, while in the fifth type cells mitochondria were abundantly scattered throughout the cytoplasm. The first, second and fourth type cells contained mitoshondria in moderate amounts. In the light of the data concerning the Golgi complex, the endoplasmic reticulum and mitochondria, it is highly probable that the third type cells represent cells in a resting stage.

Concerning the structure of the capillary wall, Romeis ('40) has shown in the human anterior pituitary that the parenchymatous cells are separated from the capillary lumən by "Grundhäutchen" 
and "Basalmembran" which are closely attached respectively with endothelial and parenchymatous cells and by "ein feiner Spaltraum" spreading out between "Grundhäutchen" and "Basalmembran." With the electron microscope, $\mathrm{F}$ a $\mathrm{rq} \mathrm{u}$ h a $\mathrm{r}$ and $\mathrm{R}$ in e hart ('55) reported similar structures in the rat anterior pituitary, which they called respectively inner and outer basement membranes and perisinusoidal space instead of "Grundhäutchen ", "Basalmembran " and "ein feiner Spaltraum." In other endocrine organs similar vascular architecture has also been demonstrated; in thyroid (Mo $\mathrm{n} \mathrm{roe,} \mathrm{'53;} \mathrm{L} \mathrm{e} \mathrm{ve} \mathrm{r,} \mathrm{'56} \mathrm{;}$ Fkhol m, '57), in parathyroid (L e ver, '56, '57; T r e r, '58), in adrenal cortex ( $\mathrm{Z}$ e la $\mathrm{n}$ de $\left.\mathrm{r},{ }^{\prime} 5 \mathrm{~T}\right)$, in pancreatic islets (Bencosme and Pease, '58) and in posterior pituitary (P a lay, '57; Bargmann and $\mathrm{KnoOp}$, '57; Hartmann, '58). The present data obtained from the mouse anterior pituitary were fundamentally similar to these studies.

On the other hand, $\mathrm{R}$ in e hart and $\mathrm{Farquhar}$ ('55) pointed out in the rat anterior pituitary that the sinusoids are lined continuously by endothelial cells possessing very delicate cytoplasm of variable thickness. In the present observations, the cytoplasm of capillary endothelial cells was spread as a thin sheet over the inner surface of the capillary basement membrane. The cytoplasm showed discontinuity in normally sectioned area and in tangential sections the discontinuity was represented by rounded pores. Discontinuity of the capillary endothelial cell cytoplasm is well known in the kidney (Rhodin, '55; Pease, '55; Bargmann, Knoop and Schiebler, '55; $\mathrm{Pak} \mathrm{Poy}$ and Robertson, '57 and others). In endocrine organs, also, the discontinuity of the endothelial cell cytoplasm was observed in the thyroid gland (Mon roe, '53; E khol m, '57), in pancreatic islets (Be ncosme and $\mathrm{Pease}$, '58), in parathyroid ( $\mathrm{Tr}$ i e r, '58), in adrenal cortex (Z e la n der, '57) and in the posterior pituitary ( $\mathrm{P}$ a l a y, '57; $\mathrm{H}$ a $\mathrm{rtm}$ an $\mathrm{n},{ }^{2} 58$ ), although absence of pores was reported in the posterior lobe of the cat and dog (Bargmann and $\mathrm{Knoop}$, '57). Moreover, the present data showed that the fenestrated cytoplasm of endothelial cells was frequently bridged by a thin membrane in agreement with the data in the rat posterior pituitary (P a la y, '57; Hartmann, '58) and in the mouse adrenal cortex ( $\mathrm{Z}$ e l a n d e $r$, '57).

Rinehart and Farquhar ('55) found fragments of the parenchymatous cell cytoplasm in the perisinusoidal space and postulated that this may be associated with the secretory mechanism 
of pituitary hormones. In the present study, however, the authors did not meet with such a phenomenon.

\section{Summary}

The anterior pituitaries of adult mice were examined with the electron microscope, and parenchymatous cells of five types were found :

1) The first type cells contained the largest cytoplasmic granules (approximately $350 \mathrm{~m} \mu$ in maximal diameter). These granules were arranged in a row at the cell periphery or in clusters in the cytoplasm. This type cell had a well-developed endoplasmic reticulum at the perinuclear region. Sinus-like dilatation of membrane bound cavities of the endoplasmic reticulum was frequently observed. The Golgi complex was variable in development from cell to cell and generally most extensive and conspicuous in moderately granulated cells. Within the Golgi area there were sometimes observed cytoplasmic granules smaller in size than those at the cell periphery. Mitochondria of variable numbers were randomly scattered in the cytoplasm.

2) The second type cells contained cytoplasmic granules (approximately $150 \mathrm{~m} \mu$ in maximal diameter) which were arranged in a row at the cell periphery or randomly scattered throughout the cytoplasm. Cytoplasmic granules were frequently found within the Golgi area. The Golgi area was well-developed in general. The endoplasmic reticulum was not so well-developed as in the first type and dilated cavities of this system were less frequently found than in the first type. Mitochondria were scattered at random throughout the cytoplasm.

3) The third type cells contained no cytoplasmic granule in the cytoplasm. As a rule these cells had no or poorly-developed endoplasmic reticulum and almost always contained no Golgi complex. Mitochondria in small numbers were scattered in the cytoplasm.

4) The fourth type cells contained cytoplasmic granules which considerably vary in shape and size. These granules were scattered individually or in small masses at the cell periphery. Frequently cytoplasmic granules were observed within the Golgi area in clusters, though smaller in size than those at the cell periphery. The Golgi area was extensive and well-defined. This type cell contained a well-developed endoplasmic reticulum. The endoplasmic reticulum 
Electron microscopic observations of the anterior pituitary of the mouse 463

showed a concentrically parallel arrangement in the cytoplasm from the perinuclear region to the cell periphery. Mitochondria were randomly scattered throughout the cytoplasm.

5) The fifth type cells contained no cytoplasmic granule, but possessed the small particles characteristic to this type cell. These small particles were diffusely scattered in considerable abundance throughout the cytoplasm. Well-developed Golgi complex and numerous mitochondria were found in this type cell.

Nuclei of these five type cells were similar in appearance. They showed fine granular appearance and had some nucleoli.

In the first and fourth type cells there were occasionally observed connections of the limiting membrane of the endoplasmic reticulum with the outer nuclear membrane and with the cell membrane.

Based on the present observations, it is clear that the first, second, and third types correspond respectively to acidophile, basophile and chromophobe cells of light microscopy, but the present authors could not identify the fourth type cell with the classification of light microscopy. It was assumed that the fifth type cell may be comparable to a transitional form(s) from the third type cell to another.

The parenchymatous cells of the mouse anterior pituitary were separated from the capillary lumen by the endothelium, inner basement membrane, perisinusoidal space and outer basement membrane. The endothelial cell cytoplasm was attenuated except for the area adjacent to the nucleus, and frequently fenestrated. The fenestration appeared as interruptions of the cytoplasm which are frequently bridged by a thin membrane in sections perpendicular to the capillary wall and as pores in tangential sections. The present authors did not encounter with fragments of the parenchymatous cells in the perisinusoidal space.

\section{Literature cited}

Af zeli us, B. A. 1956. Electron microscopy of Golgi elements in sea urchin eggs. Exp. Cell Research, 11, 67-85.

Bargma n n, W. und A. Knoop 1957. Elektronennikroskopische Beobachtungen an der Neurohypophyse. Z. Zellforsch., 46, 242-251.

Bargmann, W., A. Kn oop und Th. H. Schiebler 1955. Histologische, cytochemische und elektronenmikroskopische Untersuchungen am Nephron (mit Berücksichtigung der Mitochondrien). Z. Zellforsch., 42, 386-422.

Be a ms, H.W., T. N. Tahmis i an, R. L. Devine and E. Anderson 1956. Electron microscope studies on the dictyosomes and acroblasts in the male germ 
cells of the cricket. J. Biophysic. and Biochem. Cytol., 2 (Suppl.), 123-126.

Bencosme, S. A., and D.C. Pe as e 1958. Electron microscopy of the pancreatic islets. Endocrinol., 63, 1-13.

Bernhard, W., F. Hag ue na u, A. Gaut i e r et Ch. Ober ling 1952. La structure submicroscopique des éléments basophile cytoplasmiques dans le foie, le pancréas et les glandes salivaires. Z. Zellforsch., 37, 281-300.

Borys ko, E. 1956a. Recent developments in methacrylate embedding. I. A study of the polymerization damage phenomenon by phase contrast microscopy. J. Biophysic. and Biochem. Cytol., 2 (Suppl.), 3-14.

-1956b. Recent developments in methacrylate embedding. II. Methods for the sectioning of optically selected single cells the orientation of the plane of sectioning and the identification of the region of the specimen included in the sections. J. Biophysic. and Biochem. Cytol., 2 (Suppl.). 15-20.

Catchpole, H.R. 1949. Distribution of glycoprotein hormones in the anterior pituitary gland of the rat. J. Endocrinol., 6, 218-225.

Clermont, Y. 1956. The submicroscopic structure responsible for the cytoplasmic basophilia of the rat spermatid. Exp. Cell Research, 11, 214-217.

Dalt on, A.J. 1952. A study of the Golgi material of hepatic and intestinal epithelial cells with the electron microscope. Z. Zellforsch., 36, 522-540.

Dalton, A. J. and M.D. Feli x 1954. Cytologic and cytochemical characteristics of the Golgi substance of epithelial cells of the epididymis-in situ, in homogenates and after isolation. Am. J. anat., 94, 171-207.

1956. A comparative study of the Golgi complex. J. Biophysic. and Biochem. Cytol., 2 (Suppl.), 79-84.

Ekholm, R. 1957. The ultrastructure of the blood capillaries in the mouse thyroid gland. $Z$. Zell forsch., 46, 139-146.

F a r q u h a r, M.G. 1957. "Corticotrophs" of the rat adenohypophysis as revealed by electron microscopy. Anat. Rec., 127, 291. (abstract).

F a r quhar, M.G., and J.F. Rinehart 1954a. Electron microscopic studies of the anterior pituitary gland of castrate rats. Endocrinol., 54, 516-641.

1954b. Cytologic alterations in the anterior pituitary gland following thyroidectomy: An electron microscopic study. Endocrinol., 55, 857-876.

F a rquh a r, M.G. and S.R. Wellings 1957. Electron microscopic evidence suggesting secretory granule formation within the Golgi apparatus. J. Biophysic. and Biochem. Cytol., 3, 319-322.

Fernánde z-Morán, H. 1956. Applications of a diamond knife for ultrathin sectioning to the study of the fine structure of biological tissues and metals. J. Biophysic. and Biochem. Cytol., 2 (Suppl.), 29-30.

Fer nánde $z$-M or án, H. and R. L u f t 1949. Submicroscopic cytoplasmic granules in the anterior lobe cells of the rat hypophysis as revealed by electron microscopy. Acta endocrinol., 2, 199-211. Cited from F a r quhar and R inehart (1954a).

F in ck, H. 1958. An electron microscope study of basophile substances of frozendried rat liver. J. Biophysic. and Biochem. Cytol., 4, 291-300.

Fles ch, M. 1884. C. R. des travaux présentés à la 67. session de la Société Helvétique des Science natur., réunie à Lacarno. Arci. Sci. phys. et natur., 112. Cited from Romeis.

Freeman, J.A. 1956. The ultrastructure of the double membrane systems of mitochondria. J. Biophysic. and Biochem. Cytol., 2 (Suppl.), 353-354.

Green, J.D., and V.L. Van Breemen 1955. Electron microscopy of the pitui- 
tary and observations on neurosecretion. Am. J. Anat., 97, 177-227.

$\mathrm{H}$ a g u e $\mathrm{n}$ a $\mathrm{u}, \mathrm{F}$. and W. Be rn hard 1956. L'appareil de Golgi. Arch. Anat. micr. Morph. exp., 44, 27-53. Cited from $\mathrm{H}$ a 11 y (1958).

$\mathrm{H}$ a $11 \mathrm{y}$, A. D. 1958. The fine structure of the Peneth cell. J. Anat., 92, 268-277.

$\mathrm{H}$ a $1 \mathrm{mi}, \mathrm{N}$.S. 1950. Two types of basophils in the anterior pituitary of the rat and their respective cytophysiological significance. Endocrinol., 47, 289-299,

1952. Differentiation of two types of basophils in the adenohypophysis of the rat and mouse. Stain Technol., 27, 61-64.

Hartmann, J.F. 1958. Electron microscopy of the neurohypophysis in normal and histamin-treated rats. Z. Zellforsch., 48, 291-308.

I chikawa, A. 1959. Electron microscope study on secretion of the rat adenohypophysis. Kaibo. Z., 34, 460-482. (in Japanese with English abstract).

$\mathrm{Ki} \mathrm{rkm}$ a n, H. and A. E. Severing ha s 1938a. A review of the Golgi apparatus. I. Anat. Rec., 70, 413-431.

1938b. A review of the Golgi apparatus. II. Anat. Rec., 70, 557-573.

1938c. A review of the Golgi apparatus. III. Anat. Rec., 71, 79-103.

L a c y, D. 1957. The Golgi apparatus in neurons and epithelial cells of the common limpet Patella vulgata. J. Biophysic. and Biochem. Cytol., 3, 779-796.

L a d m a n, A. J., and W. C. Young 1958. An electron microscopic study of the ductuli efferentes and rete testis of the guinea pig. J. Biophysic. and Biochem. Cytol., 4, 219-226.

$\mathrm{L}$ a $\mathrm{t} \mathrm{ta}, \mathrm{H}$., and J.F. Hartman $\mathrm{n}$ 1950. Use of a glass edge in thin sectioning for electron microscopy. Proc. Soc. Exp. Biol. and Med., 74, 436-439.

Lever, J.D. 1956. The subendothelial space in certain endocrine tissues. J. Biophysic. and Biochem. Cytol., 2 (Suppl.), 293-294.

1957. Fine structural appearances in the rat parathyroid. J. Anat., 91, 73-81.

Mo $\mathrm{n}$ roe, B. G. 1953. Electron micrcscopy of the thyroid. Anat. Rec., 116, 345-361.

$\mathrm{Newm}$ a n, S. B., E. Borysko and M. Swerdlow 1949. Ultramicrotomy by a new mthod. J. Research Nat. Bur. Standards, 43, 183-199. Cited from Borysko (1956a).

P a k Poy, R.K.F., and J.S. Robertson 1957. Electron microscopy of the avian renal glomerules. J. Biophysic. and Biochem. Cytol., 3, 183-192.

P a l a de, G. E. 1952a. A study of fixation for electron microscopy. J. Exp. Med., 95, 285-298.

1952b. The fine structure of mitochondria. Anat. Rec., 114, 427-451.

1953. An electron microscope study of the mitochondrial structure. J. Histochem. and Cytochem., 1. 188-211. Cited from Palade (1956b).

1955a. A small particulate component of the cytoplasm. J. Biophysic. and Biochem. Cytol., 1, 59-68.

- 1955b. Studies on the endoplasmic reticulum II. Simple dispositions in cells in situ. J. Biophysic. and Biochem. Cytol., 1, 567-582.

1956a. The endoplasmic reticulum. J. Biophysic. and Biochem. Cytol., 2 (Supp1.), 85-98.

1956b. Electron microscopy of mitochondria and other cytoplasmic structures.' in Enzymes: Units of Biological Structure and Function (Henry Ford Hospital International Symposium), ed. by O. H. Ga e ble r, P. 185-215. Academic Press, New York.

P a l a de, G. E., and A. Cla ude 1949a. The nature of the Golgi apparatus. I. Pa- 
rallelism between Golgi apparatus and intracellular myellin figures. J. Morph., $85,35-69$.

1949b. The nature of the Golgi apparatus. II. Identification of Golgi ap. paratus with complex of myelin figures. J. Morph., 85, 71-111.

Pa la de, G. E., and K. R. Porter 1954. Studies on the endoplasmic reticulum. I. Its identification in cells in situ. J. Exp. Med., 100, 641-656.

$\mathrm{Pal}$ a y, S. L. 1957. The fine structure of the neurohypophysis. in Progress in Neurobiology II. Ultrastructure and Cellular Chemistry of Neural Tissue, Chap. 2, P. 31-49. ed. by Korey and Nurnberger. P. Hoeber, New York.

Pa I a y, S. L., and G. E. Palade 1955. The fine structure of neurons. J Biophysic. and Biochem. Cytol.. 1, 69-88.

Pe a r s e, A.G.E. 1949. The cytochemical demonstration of gonadotropic hormone in the human anterior hypophysis. J. Path. and Bact., 61, 195-202.

1950. Differential stain for the human and animal anterior hypophysis. Stain Technol., 25, 95-102.

1952a. Observations on the localization, nat lire and chemical constitution of some components of the anterior hypophysis. J. Path. and Bact.. 64, 791-809.

- 1952b. The cytochemistry and cytology of the normal anterior hypophysis investigated by the trichrome-periodic acid Schiff method. J. Path. and Bact., 64, $811-827$.

1953. Cytological and cytochemical investigations on the foetal and adult hypophysis in various physiological states. J. Path. and Bact., 65, 355-370.

Pe a s e, D.C. 1955. Electron microscopy of the vascular bed of the kidney cortex. Anat. Rec., 121, 701-721.

Peterson. R.R. 1957. An electron microscopic study of pituitary basophiles in the guinea pig. Anat. Rec., 127, 346. (abstract).

Porter, K.R. 1953. Observations on a submicroscopic basophilic component of cytoplasm. J. Exp. Med., 97, 727-750.

i954. Electron microscopy of basophilic components of cytoplasm. J. Histochem. and Cytochem., 2, 346-373.

Porte r, K. R., and J. B ! u m 1953. A study in microtomy for electron microfcopy. Anat. Rec., 117, 685-710.

Porter, K. R., and F. L. K a $11 \mathrm{~m}$ a n 1952. Significance of cell particulates as seen by electron microscopy. Ann. New York Acad. Sci., 54, 882-891.

Porter, K.R., and G.E. Pal ad e 1957. Studies on the endoplasmic reticulum III Its form and distribution in striated muscle cells. J. Biophysic. and Biochem. Cytol., 3, 269-300.

Purves, H. D., and W. E. Gries ba ch 1951a. The site of thyrotrophin and gonadotrophin production in the rat pituitary studied by McManus-Hotchkiss staining for glycoprotein. Endocrinol., 49, 244-264.

-1951b. Specific staining of the thyrotrophic cells of the rat pituitary by the Gomori stain. Endocrinol., 49, 427-428.

- 1951c. The significance of the Gomori staining of the basophiles of the rat pituitary. Endocrinol., 49, 652-662.

- 1954. The site of follic!e stimulating and luteinising hormone production in the rat pituitary. Endocrinol., 55, 785-793.

- 1955. Changes in the gonadotrophs of the rat pituitary after gonadectomy. Endocrinol., 56, 374-386.

Rhodin, J. 1954. Correlation of ultrastructural organization and function in normal and experimentally changed proximal convoluted tubule cells of the 
mouse kidney. Aktiebolaget Godvil, Stockholm.

1955. Electron microscopy of the glomerular capillary wall. Exp. Cell Research, 8, 572-574.

Rine hart, J.F., and M. G. Far quh a r 1953. Electron microscopic studies of the anterior pituitary gland. J. Histochem. and Cytochem., 1, 93-113.

- 1955. The fine vascular organization of the anterior pituitary gland. Anat. Rec., 121, 207-239.

Rome is, B. 1940. Hypophyse. in Handbuch der mikroskopischen Anatomie des Menschen, herausgegeben von W. v. Mölle nd or f f, Bd. 6, Tl. 3, Springer, Berlin.

Sa no, M. 1958. A new cell type of the mouse anterior pituitary. Its relation to the cyclic variations during the oestrous cycle. Folia anat. jap., 31, 17-27.

$\mathrm{Sch}$ önemann, A. 1892. Hyphphysis und Thyreoidea. Virch. Arch., 129, 310-336.

Siekevitz, P., and G. E. Palade 1958. A cytochemical study on the pancreas of the guinea pig. II. Functional variations in the enzymatic activity of microsomes. J. Biophysic. and Biochem. Cytol., 4, 309-318.

$\mathrm{S}$ jöst ra nd, F.S. 1953. System of double membranes in the cytoplasm of certain tissue cells. Nature, 171, 30-36.

$\mathrm{S}$ jös tra nd, F.S., and V. H an zon 1954a. Membrane structures of cytoplasm and mitochondria in exocrine cells of mouse pancreas as revealed by high resolution electron microscopy. Exp. Cell Research, 7, 393-414.

- 1954b. Uitrastructure of Golgi apparatus of exocrine cells of mouse pancreas. Exp. Cell Research, 7, 415-429.

$\mathrm{S} j$ öst rand, F.S. and J. Rhodin 1953. The ultrastructure of the proximal convoluted tubules of the mouse kidney as revealed by high resolution electron microscopy. Exp. Cell Research, 4, 426-456.

Trier, J.S. 1958. The fine structure of the parathyroid gland. J. Biophysic. and Biochem. Cytol., 4, 13-22.

W a t a n a be, Y. 1957. Intra-cytoplasmic sacs or cytoplasmic filamentous structure of cells. in Symposia for the Society of Cellular Chemistry, et by S. Ka t s un u ma, Vol. 5, P. 35-52. Maruzen Co., Tokyo. (in Japanese with English summary).

$\mathrm{W}$ a t a n a be, Y., M. T a k a $\mathrm{m}$ a t s u and R. Os a k o 1955. Fine structure of plasma cell as revealed by electron microscope. Electron-Microscopy, 4, 146-151. (in Japanese).

Wats on, M. L. 1955. The nuclear envelope. Its structure and relation to cytoplasmic membranes. J. Biophysic. and Biochem. Cytol., 1, 257-270.

We is s, J.M. 1953. The ergastoplasm. Its fine structure and relation to protein synthesis as studied with the electron microscope in the pancreas of the Swiss albino mouse. J. Exp. Med., 98, 607-618.

We is s, J., and A.I. Lansing 1953. Age changes in the fine structure of anterior pituitary of the mouse. Proc. Soc. Exp. Biol. and Med., 82, 460-466.

$\mathrm{Ya}$ mada, K., and M. S a n o 1958. Electron microscopic studies of the mouse anterior pituitary. Kaibo. Z., 33, 241. (Japanese abstract).

Y a mada, K., M. S a no and T. I to 1957. A postanotal histogenetic study of the anterior pituitary of the mouse. Okajimas Fol. anat. jap., 30, 177-195.

Zelander, T. 1957. The ultrastructure of the adrenal cortex of the mouse. $Z$. Zellforsch., 46, 710-716.

Zimmermann, K.W. 1927. Die Speicheldrüsen der Mundhöhle und die Bauch- 
speicheldrüse. in Handbuch der mikroskopischen Anatomien des Menschen, herausgegeben von W. v. Mölle nd o r $\mathrm{f}$ f, Bd. 5, Tl. 1, S.61-244. Springer. Berlin.

\title{
Explanation of Figures
}

\author{
Abbreviations to Figures: \\ I The first type cell \\ II The second type cell \\ III The third type cell \\ IV The fourth type cell \\ $\mathrm{V}$ The fifth type cell \\ BM Basement membrane \\ End Endothelial cell \\ F Fenestration of endothelial cell cytoplasm \\ PSS Perisinusoidal space
}

\section{Plate 1}

Fig. 1. At the center and the lower right corner, the fourth type cells are seen. Cytoplasmic granules are arranged individually or in small clusters at the cell periphery. Endoplasmic reticula show characteristic arrangement. At the upper right corner the first type cell is seen. Ih this cell, connection of the outer nuclear membane with the limiting membrane of the endoplasmic reticulum is observed. Slight dilatation of cavities of the endoplasmic reticulum is found in the second type cell at the upper left corner. $\times 5000$.

Fig. 2. Several cells of the first type are seen. In these cells sinus-like dilatation of membrane bound cavities of the endoplasmic reticulum is conspicuous and cytoplasmic ground substances scattered like islands or cords. Connections between the outer nuclear membrne and the limiting membrane of the endoplasmic reticulum are frequently observed. $\times 7250$.

Fig. 3. At the center the third type cells are seen. These cells contain mitochoneria in few number. But they have no cytoplasmic granules, no endoplasmic reticulum and no Golgi complex. At the lower right corner a part of the cytoplasm of the second type cell is observed. This cell contains regularly arranged lamellar structures (endoplasmic reticulum) and a Golgi complex. In the second type cell at the right, cytyplasmic granules are lined in a row at the cell periphery. But in the same type cell at the upper right corner the granules are randomly scattered in the cytoplasm. $\times 7250$.

\section{Plate 2}

Fig. 4. The fourth type cells are observed here and there. In these cells the endoplasmic reticulum shows a concentrical arrangement. Abundant cytoplasmic granules are concentrated in the Golgi area. These granules are smaller in size than the mature cytoplasmic granules. Two cells of the second type contain poorly-developed endoplasmic reticulum in contrast to the fourth type cells. In 
these cells cytoplasmic granules are scattered at random throughout the cytoplasm. $\times 5000$.

Fig. 5. A condensed form of the first type cell is easily recognized from its characteristic features. $\times 5000$.

Fig. 6. Two cells of the first type are seen. These cells contain well-developed Golgi complex. At the right, the fifth type cell is seen. This cell contain numerous small particles scattered randomly throughout the cytoplasm. The Golgi area of this cell is well-developed. Numerous mitochondria are contained. $\times 5000$.

\section{Plate 3}

Fig. 7. Endothelial cell cytoplasm contains mitochondria and the endoplasmic reticulum. At places the attenuated cytoplasm of the endotheilal cell shows fenestration (F). Inner and outer basement membranes and perisinusoidal space are easily recognized. $\times 7250$.

Fig. 8. An enlarged photograph of fig. 7 (area F). Fenestrations of endothelial cell cytoplasm are discernible. These fenestrations are frequently bridged by a thin membrane. $\times 25000$.

Fig. 9. In the fourth type cell dilated cavities of the endoplasmic reticulum are observed. Connection between the cell membrane and the limiting membrane of the endoplasmic reticulum is observed (indicated by arrow). Numerous cytoplasmic granules are found in the Golgi area. In the area of the endothelial cell cytoplasm sectioned tangentially, numerous pores are seen $(F) . \times 10000$.

Fig. 10. Area $\mathrm{F}$ of fig. 9 enlarged. $\times 35000$. 
Plate I
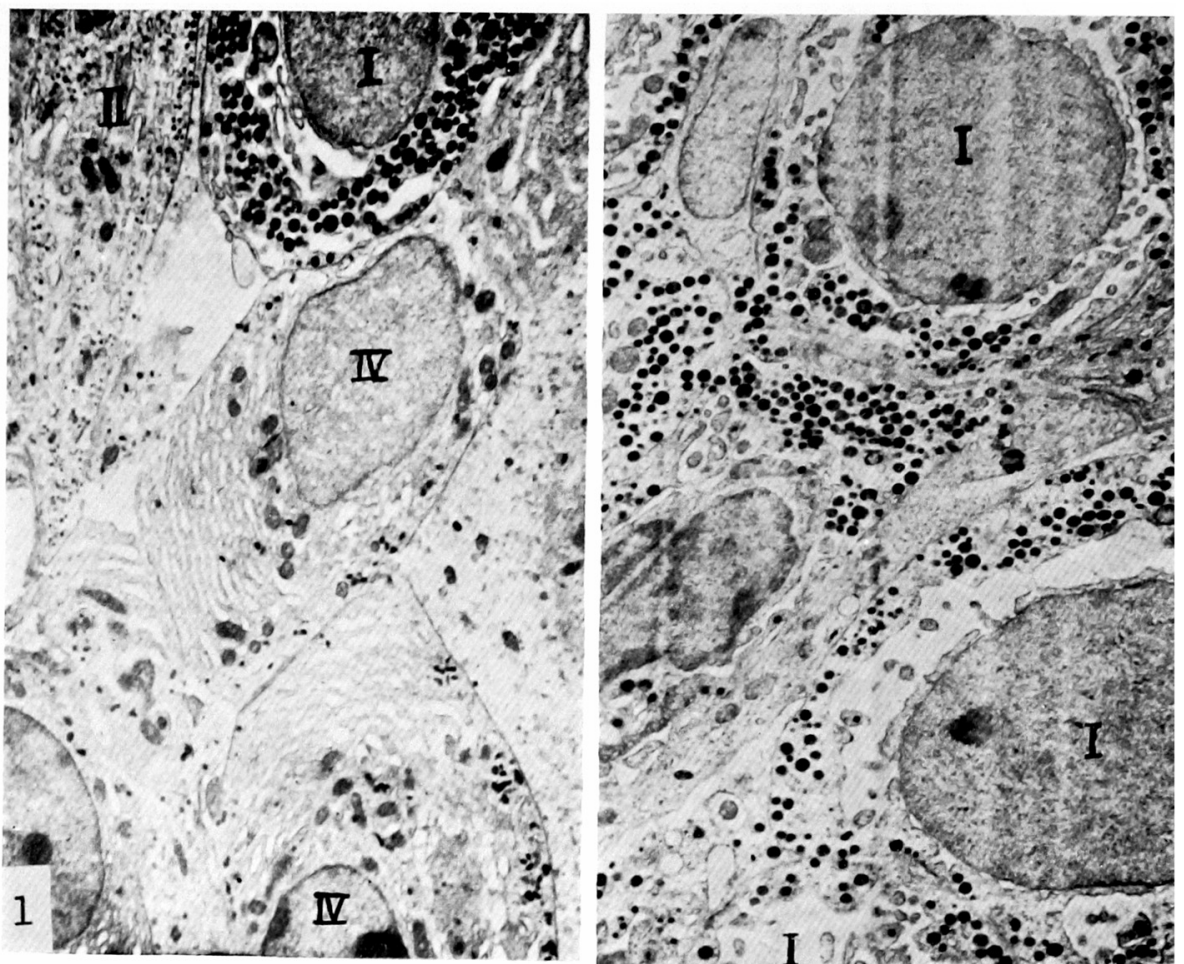

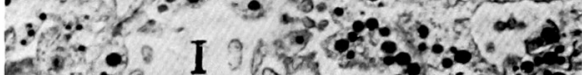

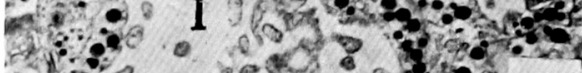

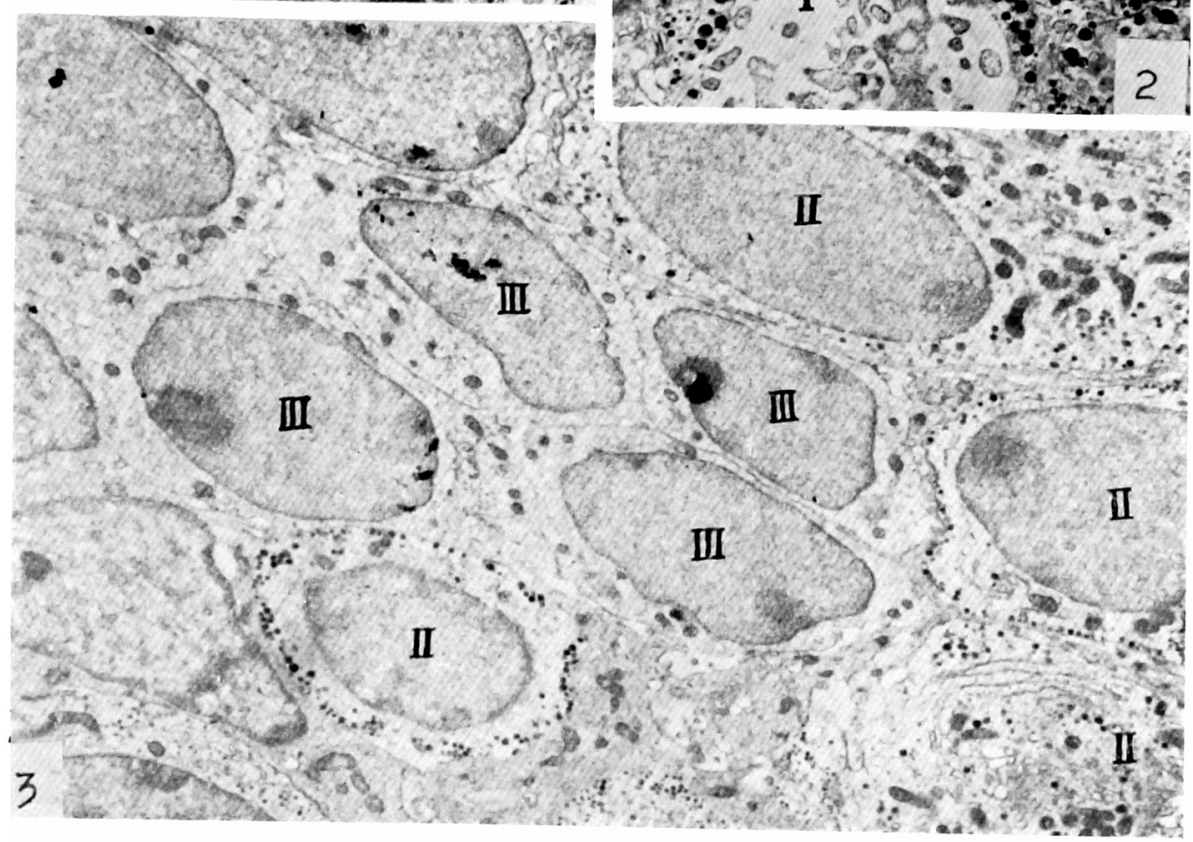

K. Yamada and M. Sano 
Plate II
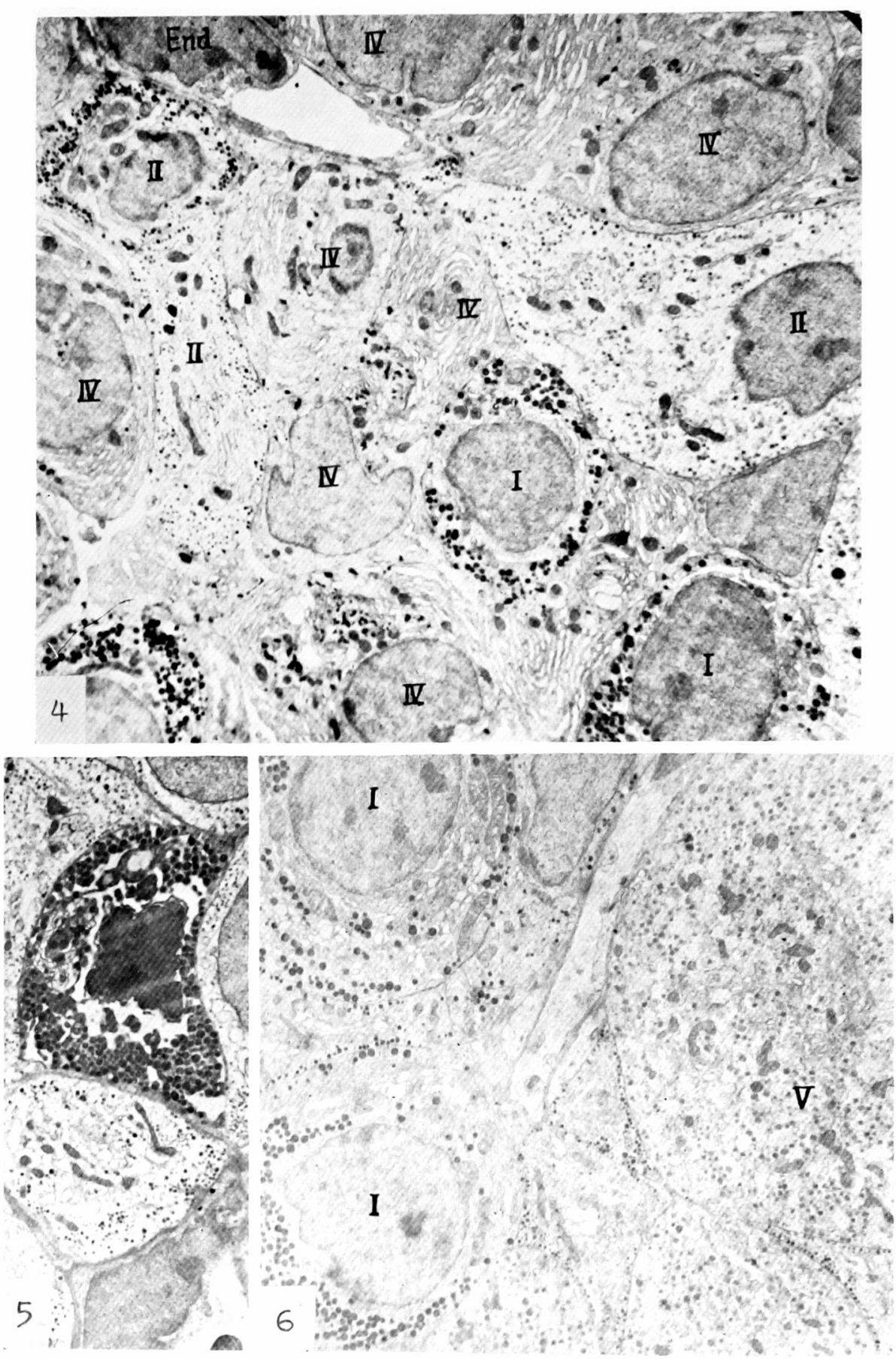

K. Yamada and M. Sano 
Plate III

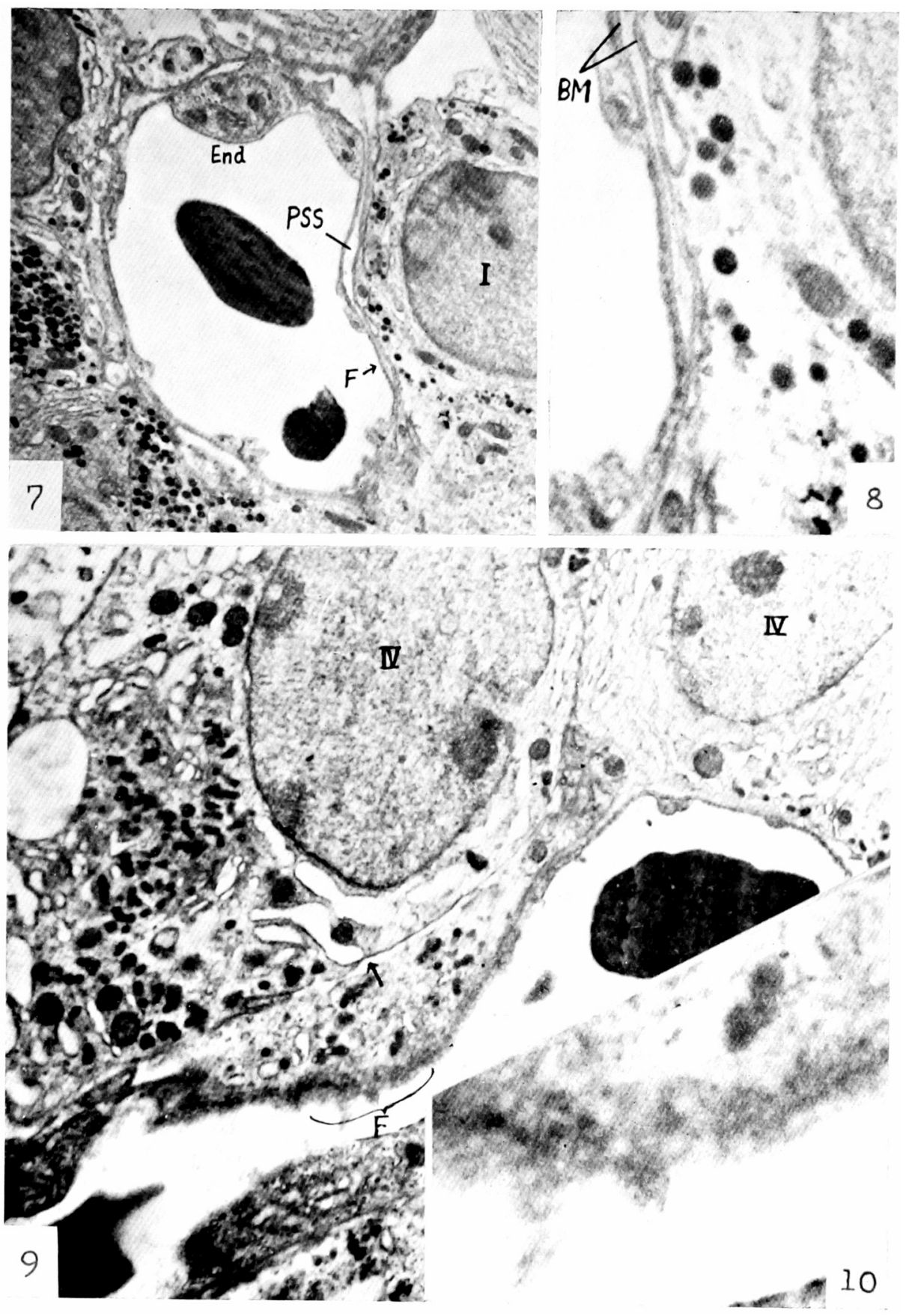

K. Yamada and M. Sano 